\title{
Critical Role of Cx40 in Reduced Endothelial Electrical Coupling by Lipopolysaccharide and Hypoxia-Reoxygenation
}

\author{
Mohammad Siddiqui ${ }^{\mathrm{a}-\mathrm{c}}$ Scott Swarbreck ${ }^{\mathrm{a}, \mathrm{c}}$ Qing Shao $^{\mathrm{d}}$ Dan Secor $^{\mathrm{a}, \mathrm{c}}$ \\ Tianqing Peng ${ }^{a, e}$ Dale W. Laird ${ }^{c, d}$ Karel Tyml ${ }^{a-c}$

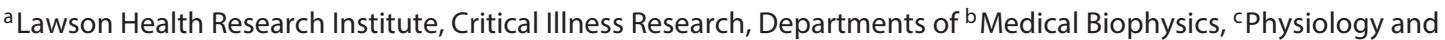 \\ Pharmacology, ${ }^{\mathrm{d}}$ Anatomy and Cell Biology, and ${ }^{\mathrm{e}}$ Medicine, University of Western Ontario, London, Ont., Canada
}

\section{Key Words}

Endothelial cells · Electrical coupling · Cx40 · Acute inflammation

\begin{abstract}
Background: We discovered that lipopolysaccharide (LPS, an initiating factor in sepsis) and hypoxia-reoxygenation $(\mathrm{H} / \mathrm{R}$, a confounding factor) reduce electrical coupling between microvascular endothelial cells from wild-type (WT) but not $\mathrm{Cx} 40^{-/-}$mice. Because $\mathrm{Cx} 40$ knockout could result in nonspecific effects, this discovery may not establish the causal relationship between $\mathrm{C} \times 40$ and reduced coupling. Using the same cell culture model, we aimed to address this uncertainty by using the rescue-of-function approach. Methods/Results: Electrical coupling between endothelial cells (hindlimb muscle origin) was determined by electrophysiology. LPS, H/R and concurrent LPS $+\mathrm{H} / \mathrm{R}$ reduced coupling between WT but not $\mathrm{C} \times 40^{-/-}$cells. The defect in $\mathrm{C} \times 40^{-/-}$cells was rescued by ectopic expression of $\mathrm{C} \times 40$, after infecting the cells with adenovirus encoding $\mathrm{C} \times 40 . \mathrm{Cx}_{4} \mathrm{O}^{-/-}$cells were also engineered to express mutant $\mathrm{Cx} 40$ that lacked the carboxyl terminal domain beginning at residue $236\left(\mathrm{C} \times 40_{\Delta 237-358}\right)$ or $344\left(\mathrm{Cx}_{40}{ }_{\triangle 345-358}\right)$. No response to inflammatory stimuli was observed in cells expressing either of these 2 mutants. Conclusion: Our data establish the causal relationship between
\end{abstract}

(c) 2016 S. Karger AG, Base

$1018-1172 / 16 / 0526-0396 \$ 39.50 / 0$
Cx40 and reduced coupling and suggest that the 345-358 amino acid motif of the $C x 40$ carboxyl terminal is required for reduced coupling. Cx40 may participate in compromised conducted response in the microvasculature during sepsis.

(c) 2016 S. Karger AG, Basel

\section{Introduction}

Sepsis is a systemic inflammatory response to local infection. We have shown that sepsis attenuates the arteriolar conducted response, thus contributing to hemodynamic failure $[1,2]$. The response involves the passage of electrical currents along the endothelial layer of the arteriole via interendothelial gap junctions [3]. To explain the attenuated conduction, we used electrophysiology and monolayers of cultured microvascular endothelial cells (MMEC, of mouse skeletal muscle origin) to discover that lipopolysaccharide (LPS, an initiating factor in sepsis) and hypoxia-reoxygenation ( $\mathrm{H} / \mathrm{R}$, a confounding factor) reduce electrical coupling in cells from wild-type (WT), $\mathrm{Cx} 37^{-/-}$and $\mathrm{C} \times 43^{\mathrm{G} 60 \mathrm{~S}}$ 'non-functional' mutants, but not from $\mathrm{Cx} 40^{-/-}$mice (review [4]). These results suggested a causal relationship between $\mathrm{Cx} 40$ and reduced coupling after exposure to the inflammatory stimuli. However, because MMEC express a low level of Cx40 protein [5], it

\section{KARGER 125}

E-Mail karger@karger.com www.karger.com/jvr
Dr. Karel Tyml

Lawson Health Research Institute, Critical Illness Research

800 Commissioners Rd. E.

London, ON N6C 2V5 (Canada)

E-Mailktyml@lhsc.on.ca 
was not clear how $\mathrm{Cx} 40$ dictates the response to the stimuli in the presence of other more abundant connexins.

It has been reported that $\mathrm{Cx} 43$ knockout in mice affects the expression of numerous proteins [6]. Cx40 knockout can result in nonspecific effects [7]. To address this issue, the main objective of this study was to use the 'rescue-of-function' approach in $\mathrm{Cx} 40^{-/-}$cells, by reintroducing Cx40 into the cells by infecting them with an adenovirus encoding $\mathrm{Cx} 40$. If the loss of response to the stimuli were due to a nonspecific effect, then introduction of Cx40 would not rescue the response. A further objective was to probe for a critical motif of $\mathrm{Cx} 40$ responsible for the response. To this end, we engineered $\mathrm{Cx} 40^{-/-}$cells to express 2 mutants of $\mathrm{Cx} 40$ that lacked the specific carboxyl terminal (CT) domains of $\mathrm{Cx} 40$. We hypothesized that either deletion mutant may eliminate the anticipated rescue of response in $\mathrm{Cx} 40^{-/-}$cells.

\section{Methods}

Reagents, mouse strains, isolation and culturing of MMEC, electrophysiological approach (i.e. injection of 2-4 hyperpolarizing constant-current pulses of $25 \mathrm{nA}$ and $100 \mathrm{~ms}$ duration at 1second intervals into cell monolayers), treatment with LPS, H/R and concurrent LPS $+\mathrm{H} / \mathrm{R}$ as well as quantitative PCR, immunofluorescence and Western blot analyses were all based on our published reports $[5,8,9]$, and are therefore included in the electronic supplement (Methods; for all online suppl. material, see www.karger.com/doi/10.1159/000445772).

\section{Recombinant Adenovirus}

Adenoviruses (AdV) carrying cDNA of $\beta$-galactosidase (AdV$\beta$-gal), WT Cx40 (AdV-Cx40) and $\mathrm{Cx} 40$ truncated at CT residues $236\left(\mathrm{AdV}-\mathrm{Cx} 40_{\Delta 237-358}\right)$ and $344\left(\mathrm{AdV}-\mathrm{Cx} 40_{\Delta 345-358}\right)$ were separately cloned and supplied by Applied Biological Materials Inc. (Vancouver, B.C., Canada). The viruses were amplified using a standard procedure using human embryonic kidney 293 cells. They were purified and titrated with the adenovirus purification mega kit and adenovirus titer immunoassay kit, respectively, following the manufacturer's instructions. We applied Adv-Cx40, $\mathrm{AdV}-\mathrm{Cx} 40_{\triangle 237-358}$ or AdV-Cx40 $4345-358$ to MMEC harvested from $\mathrm{Cx} 40^{-/-}$mice (70-75\% confluent monolayers) at a multiplicity of infection $50 \mathrm{IFU} /$ cell, and further incubated for $24 \mathrm{~h}$. AdV- $\beta$-gal was used in parallel as a negative control. Successful infection was determined by detection of $\mathrm{Cx} 40 \mathrm{mRNA}$ and $\mathrm{Cx} 40$ protein expression in infected $\mathrm{Cx} 40^{-/-}$cells.

\section{Statistical Analysis}

The data are presented as mean \pm standard error. MMEC were isolated from at least 3 different mice ( $\mathrm{n}$ indicates the number of monolayers used per treatment group, unless otherwise stated). Statistical significance was assessed using ANOVA and two-tailed Student's t test with Bonferroni's correction, unless otherwise stated. Significance was set to $\mathrm{p}<0.05$.

Cx40 Is Required for Reduced Electrical

Coupling

\section{Results}

\section{Cell Morphology and Baseline Resting Membrane}

Potential

LPS $(10 \mu \mathrm{g} / \mathrm{ml}, 1 \mathrm{~h}), \mathrm{H} / \mathrm{R}\left(0.1 \% \mathrm{O}_{2}\right.$ for $1 \mathrm{~h}$, followed by 5-20 min reoxygenation), or LPS $+\mathrm{H} / \mathrm{R}$ stimuli did not result in any visual morphological changes in the appearance of the cell monolayers. Resting membrane potential $\left(\mathrm{E}_{\mathrm{m}}\right)$ values for $\mathrm{Cx} 40^{-/-}, \mathrm{Cx} 40^{-/-}+\mathrm{AdV}-\mathrm{Cx} 40, \mathrm{Cx} 40^{-/-}+$

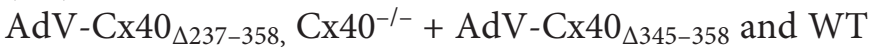
cells were $-12.7 \pm 4.1(\mathrm{n}=22),-13.2 \pm 6.0(\mathrm{n}=16),-12.7$ $\pm 3.3(\mathrm{n}=8),-14.1 \pm 4.2(\mathrm{n}=11)$ and $-13.5 \pm 6.5 \mathrm{mV}$ $(n=6)$, respectively. The values did not differ between groups. The values were less than those reported in in vivo or ex vivo preparations [10], but they fell within the range reported for cultured endothelial cells [11, 12]. Resting $\mathrm{E}_{\mathrm{m}}$ values remained unchanged after cell exposure to the inflammatory stimuli.

\section{Effect of LPS, H/R and LPS $+H / R$ on Coupling in CX40-/- and WT Cells}

To assess coupling, we used a method of constant-current pulse injection into the cell monolayer (electronic supplement, Methods; a simple model of the method is shown in online suppl. fig. S1). In practice, we measured current-induced $\mathrm{E}_{\mathrm{m}}$ deflections mostly at 50-, 150- and $250-\mu \mathrm{m}$ distances from the injection electrode (fig. 1). The largest deflections occurred at $50 \mu \mathrm{m}$ (summarized in online suppl. fig. S2). From the spatial decay of these deflections, we computed the intercellular resistance $\left(r_{i}\right)$. The legend to figure 1 provides examples of computed $r_{i}$ for both $\mathrm{Cx} 40^{--}$and $\mathrm{Cx} 40^{-/-}+\mathrm{AdV}-\mathrm{Cx} 40$ cells under control and LPS conditions. Figure $2 \mathrm{a}$ summarizes percent $r_{i}$ changes from control for $\mathrm{Cx} 40^{-/-}, \mathrm{Cx} 40^{-/-}+\mathrm{AdV}$ Cx40 and WT cells exposed to LPS, H/R and LPS + H/R. The stimuli did not affect $\mathrm{r}_{\mathrm{i}}$ in $\mathrm{Cx} 40^{-/-}$cells, but they increased $\mathrm{r}_{\mathrm{i}}$ (i.e. reduced electrical coupling) in the $\mathrm{Cx} 40^{-/-}$ + AdV-Cx40 and WT cells. Thus, ectopically expressed Cx40 in Cx40 ${ }^{-/-}$cells rescued the response to these stimuli. The transmembrane resistivity in $\mathrm{Cx} 40^{-/-}$cells $(9.5 \pm$ $5.9 ; \mathrm{n}=22), \mathrm{Cx} 40^{-/-}+\mathrm{AdV}-\mathrm{Cx} 40$ cells $(11.5 \pm 7.6 ; \mathrm{n}=16)$ and WT cells $\left(7.6 \pm 1.7 \mathrm{k} \Omega \mathrm{cm}^{2} ; \mathrm{n}=6\right)$ was not altered by the inflammatory stimuli. The data for $\mathrm{Cx} 40^{-/-}$and WT cells (fig. 2a) showing a larger effect of LPS $+H / R$ when compared to LPS or H/R alone agree with our previous work with these cells [9].

Figure $2 \mathrm{~b}$ summarizes $\mathrm{r}_{\mathrm{i}}$ data from $\mathrm{Cx} 40^{-/-}$cells expressing either of the $2 \mathrm{Cx} 40$ mutants. LPS did not affect $\mathrm{r}_{\mathrm{i}}$ in $\mathrm{Cx} 40^{-/-}+\mathrm{AdV}-\mathrm{Cx} 40_{\Delta 237-358}$ or $\mathrm{Cx} 40^{-/-}+\mathrm{AdV}-$ Cx $40_{\Delta 345-358}$ cells. LPS did not affect $r_{i}$ in $\mathrm{Cx} 40^{-/-}+$ 

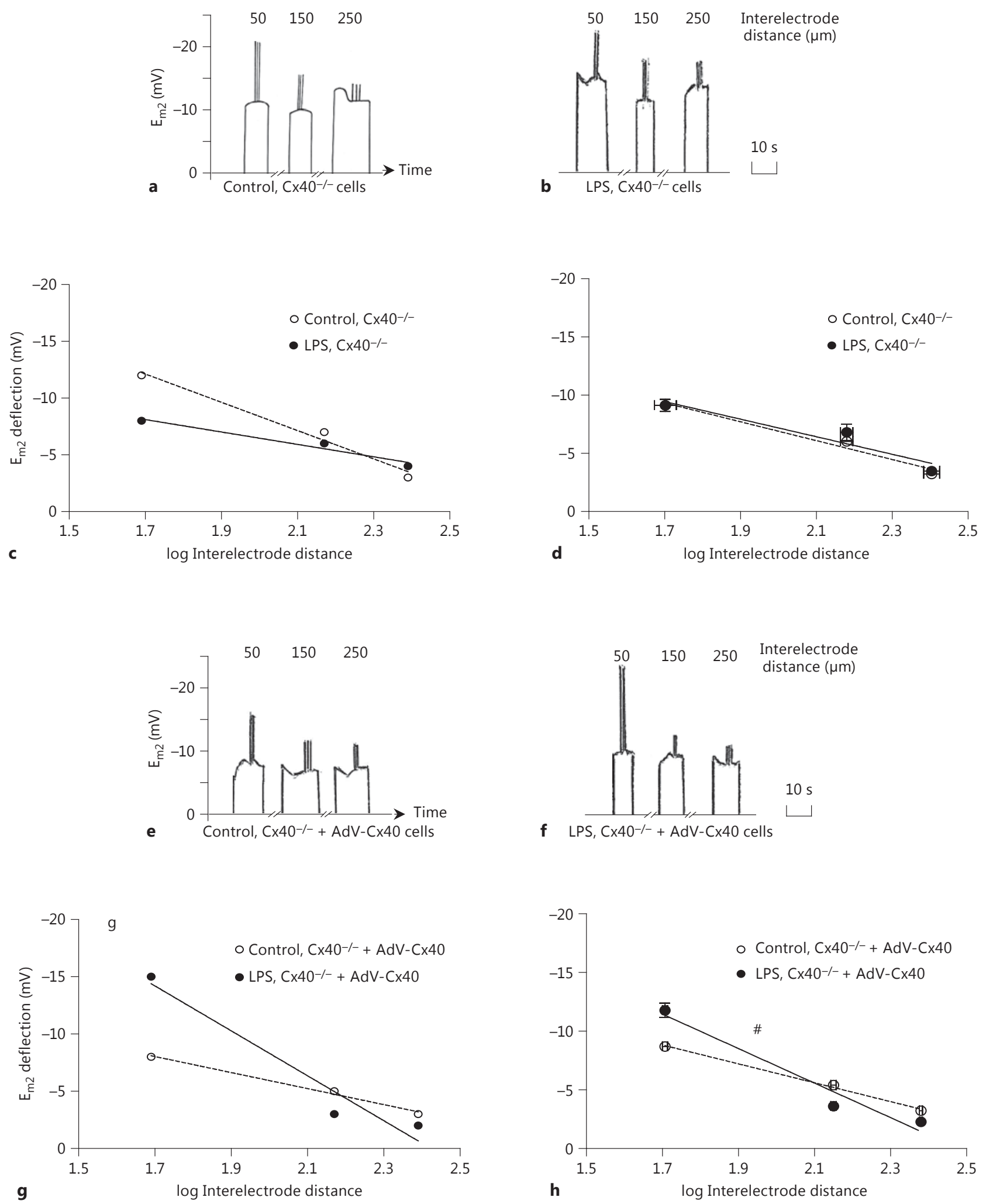

1

(For legend see next page.) 
AdV- $\beta$-gal cells (legend to fig. $2 b$ ). Similarly, H/R did not affect $\mathrm{r}_{\mathrm{i}}$ in $\mathrm{Cx} 40^{-/-}+\mathrm{AdV}-\mathrm{Cx} 40_{\Delta 237-358}$ or $\mathrm{Cx} 40^{-/-}+$ $\mathrm{AdV}-\mathrm{Cx} 40_{\Delta 345-358}$ cells. Thus, the mutants failed to rescue the response to these stimuli, suggesting a critical role of Cx40 residues 345-358 in the response. The transmembrane resistivity in $\mathrm{Cx} 40^{-/-}+\mathrm{AdV}-$ Cx40 $4237-358$ cells $(9.6 \pm 5.2, \mathrm{n}=8)$ and $\mathrm{Cx} 40^{-/-}+\mathrm{AdV}$ $\mathrm{Cx} 40_{\triangle 345-358}$ cells $\left(10.1 \pm 6.5 \mathrm{k} \Omega \mathrm{cm}^{2}, \mathrm{n}=11\right)$ was not altered by the stimuli.

\section{Detection of Cx40 mRNA}

Based on the real-time PCR in $\mathrm{Cx} 40^{-/-}$cells, infected $\mathrm{Cx} 40^{-1-}$ cells and WT cells, and on measured Ct values for $\beta$-actin and Cx40 mRNA expressions in these cells, the average fold increases of $\mathrm{Cx} 40 \mathrm{mRNA}$ expression in $\mathrm{Cx} 40^{-/-}+\mathrm{AdV}-\mathrm{Cx} 40, \mathrm{Cx} 40^{-/-}+\mathrm{AdV}-\mathrm{Cx} 40_{\triangle 237-358}$ and $\mathrm{Cx} 40^{-/-}+\mathrm{AdV}-\mathrm{Cx} 40_{\triangle 345-358}$ cells were $22.0,17.5$ and 12.2 , respectively, relative to the $\mathrm{Cx} 40 \mathrm{mRNA}$ expression in WT cells (online suppl. fig. S3). No Cx40 mRNA was detected in the $\mathrm{Cx} 40^{-/-}$cells.

\section{Detection of Cx40 Protein}

Using the anti-Cx40 antibody targeting $\mathrm{Cx} 40 \mathrm{CT}$ (Alpha Diagnostics), no Cx40 protein was detected by immunofluorescence in the $\mathrm{Cx} 40^{-/-}$cells, as expected (fig. 3a). In contrast, $\mathrm{Cx} 40$ protein plaques were detected with the same antibody in $\mathrm{Cx} 40^{-/-}+\mathrm{AdV}-\mathrm{Cx} 40$ cells (fig. 3b), indicating successful infection with $\mathrm{AdV}-\mathrm{Cx} 40$ (presumably, some of the Cx40 plaques would be gap junction plaques). $\mathrm{Cx} 40$ protein was also detected with this antibody in the WT cells, but to a lesser extent than in the infected cells (fig. 3c). The low number of $\mathrm{Cx} 40$ protein plaques in the WT cells was consistent with our previous report of a low level of $\mathrm{Cx} 40$ protein expression in WT MMEC probed by immunofluorescence [5]. No $\mathrm{Cx} 40$ protein was detected in a negative control experiment in the WT cells where the anti-Cx40 antibody was omitted (data not shown).

Next, we used the Invitrogen anti-Cx40 antibody (i.e. the only available antibody not requiring $\mathrm{Cx} 40 \mathrm{CT}$ for $\mathrm{Cx} 40$ detection) to probe for $\mathrm{Cx} 40$ in $\mathrm{Cx} 40^{-/-}+\mathrm{AdV}$ $\mathrm{Cx} 40_{\triangle 345-358}$ cells. The performance of this antibody was disappointing. Unlike the Alpha Diagnostics antibody showing no $\mathrm{Cx} 40$ protein in the $\mathrm{Cx} 40^{-/-}$cells, it showed nonspecific staining in the $\mathrm{Cx} 40^{-/-}$cells (fig. $3 \mathrm{~d}$ ). Despite this drawback, it did detect $\mathrm{Cx} 40$ protein plaques in $\mathrm{Cx} 40^{-/-}+\mathrm{AdV}-\mathrm{Cx} 40_{\Delta 345-358}$ cells (fig. $3 \mathrm{e}$ ), indicating successful infection with $\mathrm{AdV}-\mathrm{Cx} 40_{\Delta 345-358}$. $\mathrm{Cx} 40$ plaques were also detected with this antibody in the WT cells (fig. 3f), but to a lesser extent than the infected cells.

To extend our immunofluorescence results, we used Western blotting to show that WT cells infected with AdV-Cx40 express Cx40 protein. We used the Zymed anti-Cx40 antibody (the Alpha Diagnostics and Invitrogen antibodies did not work). Online supplementary figure S4 shows negligible $\mathrm{Cx} 40$ protein expression in WT cells, but noticeable expression in WT $+\mathrm{AdV}-\mathrm{Cx} 40$ cells. The low/negligible $\mathrm{Cx} 40$ presence in putative gap junction plaques in WT cells was confirmed with immunofluores-
Fig. 1. Examples of electrophysiological recordings in microvascular endothelial cells obtained from hind-limb skeletal muscle of $\mathrm{Cx} 40^{-/-}$mice. a A situation for the control $\mathrm{Cx} 40^{-/-}$cell monolayer where a cell was impaled by a current-injecting electrode $\mathrm{E}_{1}$ (not shown). Subsequently, a recording electrode $\mathrm{E}_{2}$ impaled another cell in the monolayer at a $50-\mu \mathrm{m}$ interelectrode distance at the time marked by the step change in membrane potential $\mathrm{E}_{\mathrm{m} 2}$ from 0 to $-12 \mathrm{mV}$. Next, electrode $\mathrm{E}_{1}$ injected 3 brief constant-current pulses into the first cell, causing brief superimposed $\mathrm{E}_{\mathrm{m} 2}$ deflections of -10 $\mathrm{mV}$. The step change in $\mathrm{E}_{\mathrm{m} 2}$ to zero marks the time of electrode $\mathrm{E}_{2}$ withdrawal from the cell. The procedure was repeated for interelectrode distances of 150 and $250 \mu \mathrm{m}$, and $\mathrm{E}_{\mathrm{m} 2}$ deflections for all distances were used to compute $r_{i}$ (an inverse measure of electrical coupling) as detailed in Electronic Supplement, Methods. b Examples of $\mathrm{E}_{\mathrm{m} 2}$ recordings from $\mathrm{Cx} 40^{-/-}$monolayer exposed to LPS $(10 \mu \mathrm{g} / \mathrm{ml}$ for $1 \mathrm{~h})$. $\mathbf{c}$ A plot of $\mathrm{E}_{\mathrm{m} 2}$ deflections of $\mathbf{a}$ and $\mathbf{b}$ against the $\log$ of interelectrode distance. Lines represent the best fit through the points. Based on these plots, $r_{i}$ was computed as 1.6 and $1.4 \mathrm{M} \Omega$ for the control LPS conditions, respectively. $\mathbf{d}$ Lines of best fit of $\mathrm{E}_{\mathrm{m} 2}$ deflections from all experiments in $\mathbf{c}$. There was no difference in slopes between the control and LPS conditions. $\mathrm{n}=35$ deflections (1 deflection/each impaled cell) at 50 - $\mu \mathrm{m}$ interelectrode distance, 1 at $75 \mu \mathrm{m}, 30$ at $150 \mu \mathrm{m}, 2$ at $175 \mu \mathrm{m}, 31$ at $250 \mu \mathrm{m}, 1$ at $275 \mu \mathrm{m}$ and 2 at $300 \mu \mathrm{m}$ for the control, and 14 at $50 \mu \mathrm{m}, 1$ at $75 \mu \mathrm{m}, 19$ at 150 $\mu \mathrm{m}, 2$ at $175 \mu \mathrm{m}, 14$ at $250 \mu \mathrm{m}, 1$ at $275 \mu \mathrm{m}$ and 1 at $300 \mu \mathrm{m}$ for LPS in $\mathrm{Cx} 40^{-/-}$cells. e, $\mathbf{f}$ Examples of $\mathrm{E}_{\mathrm{m} 2}$ recordings from $\mathrm{Cx} 40^{-/-}+$ $\mathrm{AdV}-\mathrm{Cx} 40$ monolayer subjected to control and LPS conditions. $\mathbf{g}$ A plot of $\mathrm{E}_{\mathrm{m} 2}$ deflections of $\mathbf{e}$ and $\mathbf{f}$ against the log of interelectrode distance. We computed $r_{i}=1.5$ and $4.3 \mathrm{M} \Omega$ for the control and LPS conditions, respectively. $\mathbf{h}$ Lines of best fit of $\mathrm{E}_{\mathrm{m} 2}$ deflections from all experiments exemplified in $\mathbf{g}$. The slope for the LPS condition was significantly larger when compared to the control, demonstrating that LPS increased the slope only in the $\mathrm{Cx} 40^{-/-}+$ $\mathrm{AdV}-\mathrm{Cx} 40$ monolayer, i.e. when $\mathrm{Cx} 40$ was ectopically expressed in Cx40 ${ }^{-1-}$ cells. ${ }^{\#} \mathrm{p}<0.05$ compared to control, using the GraphPad program for comparisons between slopes, $\mathrm{n}=29$ deflections at 50 $\mu \mathrm{m}, 1$ at $75 \mu \mathrm{m}, 4$ at $100 \mu \mathrm{m}, 1$ at $125 \mu \mathrm{m}, 30$ at $150 \mu \mathrm{m}, 4$ at $200 \mu \mathrm{m}$, 28 at $250 \mu \mathrm{m}$ and 2 at $300 \mu \mathrm{m}$ for the control, and 35 at $50 \mu \mathrm{m}, 2$ at $75 \mu \mathrm{m}, 4$ at $100 \mu \mathrm{m}, 1$ at $125 \mu \mathrm{m}, 25$ at $150 \mu \mathrm{m}, 4$ at $200 \mu \mathrm{m}, 21$ at $250 \mu \mathrm{m}$ and 2 at $300 \mu \mathrm{m}$ for LPS in Cx40 $0^{-/-}+\mathrm{AdV}-\mathrm{Cx} 40$ cells. 


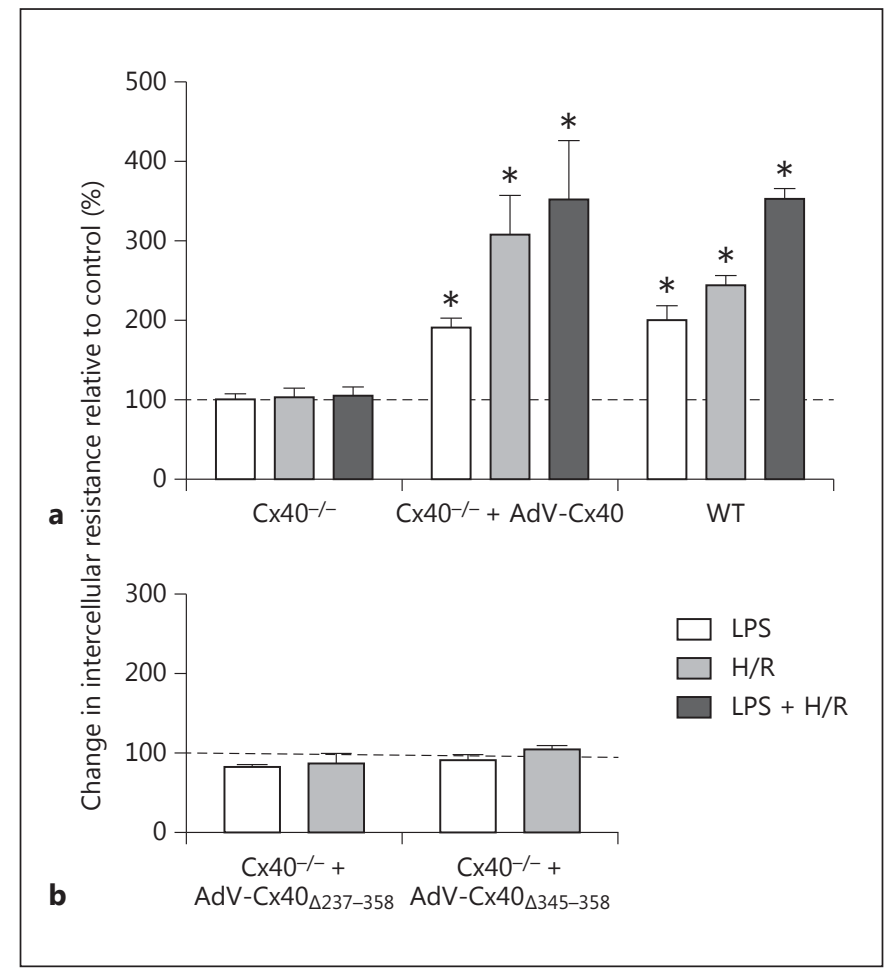

Fig. 2. Effect of inflammatory stimuli on $r_{i}$ in mouse microvascular endothelial cells. We used LPS $(10 \mu \mathrm{g} / \mathrm{ml}$, for $1 \mathrm{~h})$, hypoxia $(0.1 \%$ $\mathrm{O}_{2}$ for $1 \mathrm{~h}$ ) and reoxygenation (5-20 min), i.e. H/R, and concurrent LPS $+H / R$. a Percentage changes in $r_{i}$ with respect to control $r_{i}$ are shown for $\mathrm{Cx} 40^{-/-}, \mathrm{Cx} 40^{-/-}+\mathrm{AdV}-\mathrm{Cx} 40$, and WT cells. Control $\mathrm{r}_{\mathrm{i}}$ values: $1.4 \pm 0.3 \mathrm{M} \Omega, 1.5 \pm 0.3 \mathrm{M} \Omega$ and $1.5 \pm 0.6 \mathrm{M} \Omega$ in $\mathrm{Cx} 40^{-/-}$ cells, $1.3 \pm 0.5 \mathrm{M} \Omega, 0.9 \pm 0.1 \mathrm{M} \Omega$, and $1.2 \pm 0.5 \mathrm{M} \Omega$ in $\mathrm{Cx} 40^{-/-}+$ AdV-Cx 40 cells and $1.3 \pm 0.3 \mathrm{M} \Omega, 1.3 \pm 0.2 \mathrm{M} \Omega$ and $1.3 \pm 0.2 \mathrm{M} \Omega$ in WT cells before stimulation with LPS, H/R and LPS $+\mathrm{H} / \mathrm{R}$, respectively. ${ }^{*} \mathrm{p}<0.05$ compared to the respective control group, $\mathrm{n}=4-22$ cell monolayers per group. $\mathbf{b}$ Percentage changes in $r_{i}$ are shown for $\mathrm{Cx} 40^{-/-}+\mathrm{AdV}-\mathrm{Cx} 40_{\Delta 237-358}$ and $\mathrm{Cx} 40^{-/-}+\mathrm{AdV}-$ $\mathrm{Cx} 40_{\Delta 345-358}$ cells. Control $\mathrm{r}_{\mathrm{i}}$ values: $1.6 \pm 0.2 \mathrm{M} \Omega$ and $1.5 \pm 0.2 \mathrm{M} \Omega$ in $\mathrm{Cx} 40^{-/-}+\mathrm{AdV}-\mathrm{Cx} 40_{\Delta 237-358}$ cells and $1.4 \pm 0.3 \mathrm{M} \Omega$ and $1.6 \pm$ $0.3 \mathrm{M} \Omega$ in $\mathrm{Cx} 40^{-/-}+\mathrm{AdV}-\mathrm{Cx} 40_{\Delta 345-358}$ cells before stimulation with LPS and H/R, respectively ( $\mathrm{n}=4-6$ per group). For $\mathrm{Cx} 40^{-/-}+$ AdV- $\beta$-gal cells, the percent change after LPS was $94 \pm 6 \%$ of the control value. The control $r_{i}$ was $1.5 \pm 0.3 \mathrm{M} \Omega(\mathrm{n}=6$ per group). Inflammatory stimuli increased $r_{i}$ (i.e. reduced electrical coupling) only in $\mathrm{Cx} 40^{-/-}$cells infected with AdV-Cx40 and in WT cells.

cence using Zymed and Chemicon antibodies, in both untreated and LPS-treated cells (online suppl. fig. S5). Taken together, infection with AdV-Cx40 increased Cx40 protein expression in $\mathrm{Cx} 40^{-/-}$cells when examined by immunofluorescence (compare fig. 3a, b) as well as in WT cells when examined by Western blot (online suppl. fig. S4).

\section{Discussion}

This study shows, for the first time, that the introduction of WT $\mathrm{Cx} 40$ into $\mathrm{Cx} 40^{-/-}$microvascular endothelial cells rescues the reduction in electrical coupling initiated by LPS, H/R and LPS + H/R, thus establishing a causative link between $\mathrm{Cx} 40$ and the reduction. Moreover, our data show that the introduction of $\mathrm{Cx} 40$ without the residues 345-358 does not rescue the reduction, suggesting that this Cx40CT domain is required for the reduced coupling.

\section{Methodological Considerations}

Two issues are considered. First, there was a methodological difficulty in accurately determining the baseline $r_{i}\left(\right.$ i.e. control $\left.r_{i}\right)$. This determination depends on a number of parameters (e.g. monolayer confluency and thickness, number of gap junctions between adjacent cells and connexin composition of gap junctions). Because the accurate determination of all these parameters was technically very difficult on an experimental day-to-day basis, the study was designed in the following way. For each cell line prepared for a particular experimental day, we passaged cells to an appropriate number of monolayer-covered coverslips. Then, on the experimental day, we randomly assigned coverslips to the control or treatment group (electronic supplement, Methods). This procedure permitted a comparison between $r_{i}$ in the control and treatment groups within a cell line, but no comparison between baseline $r_{i}$ among different cell lines studied on different days. Thus, because of the technical difficulty in controlling all parameters required for computing the baseline $r_{i}$, our results did not lend themselves to establish an effect of $\mathrm{Cx} 40$ knockout and $\mathrm{Cx} 40$ infection on baseline $r_{i}$.

The second issue is the low $\mathrm{Cx} 40$ protein expression seen in WT cells and in cells infected with AdV-Cx40 (fig. 3; online suppl. fig. S4). Cx40 protein is abundantly expressed in the endothelium of mammalian microvasculature in vivo [13]. However, exposure of endothelial cells to culturing conditions may profoundly diminish their protein expression. For example, cell passaging caused a marked loss of CD14 protein in HUVEC [14]. In cultured microvascular endothelial cells obtained from rat skeletal muscle, we detected a high level of $\mathrm{Cx} 40$ mRNA, but no Cx40 protein [15]. Posttranslational modifications associated with cell culturing and/or compensation by other connexins as well as the poor performance of commercial $\mathrm{Cx} 40$ antibodies, could have contributed to this lack of detection. The loss of protein in 


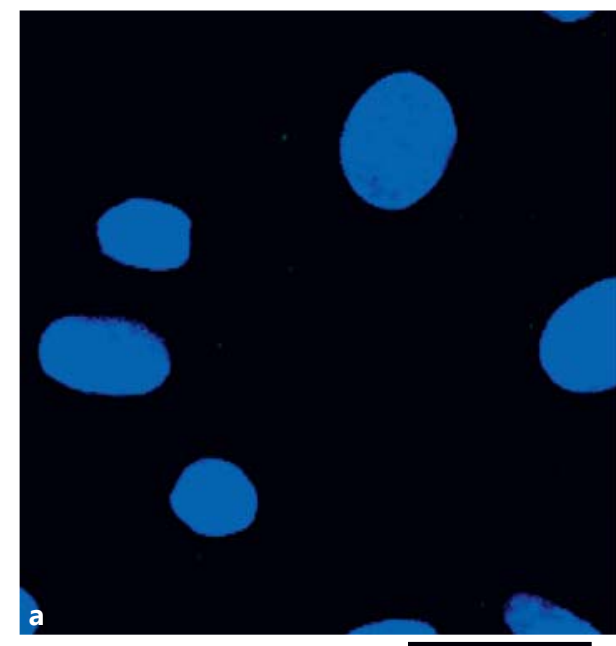

Cx40-1-

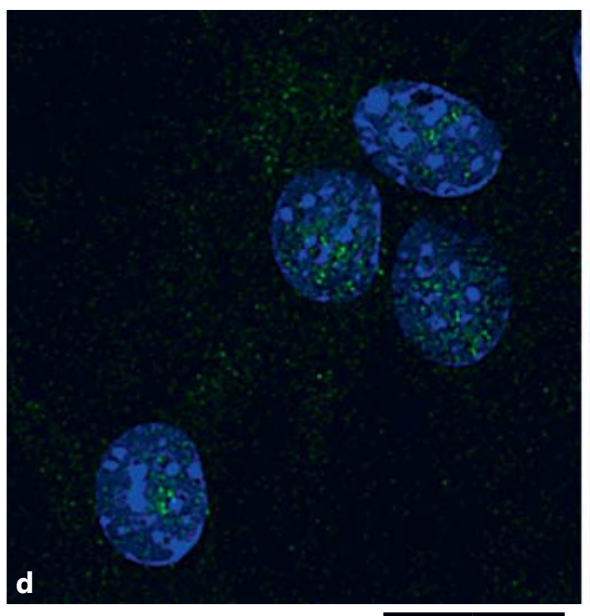

Cx40-1-

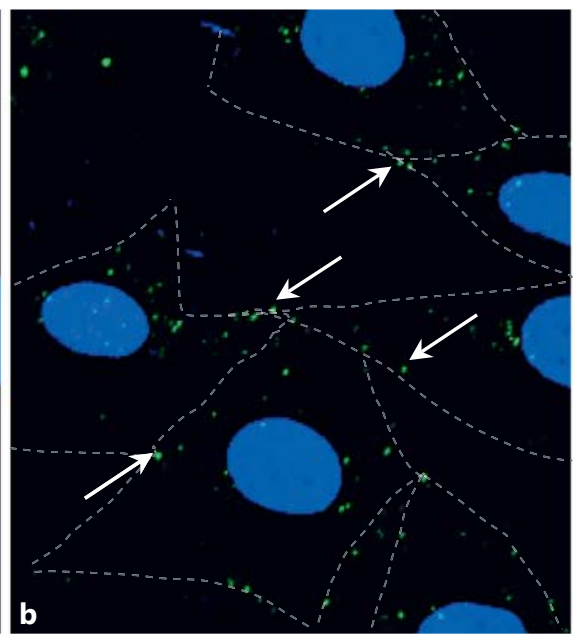

$\mathrm{Cx} 40^{-/-}+\mathrm{AdV}-\mathrm{C} \times 40$

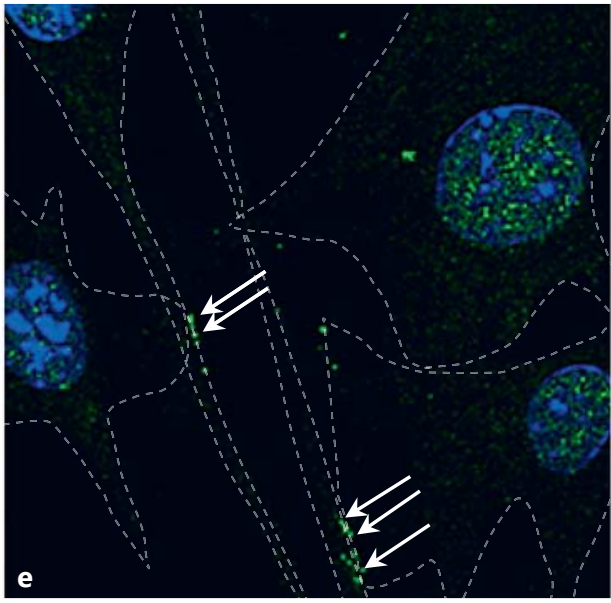

$\mathrm{C} \times 40^{-/-}+\mathrm{AdV}-\mathrm{C} \times 40_{\Delta 345-358}$

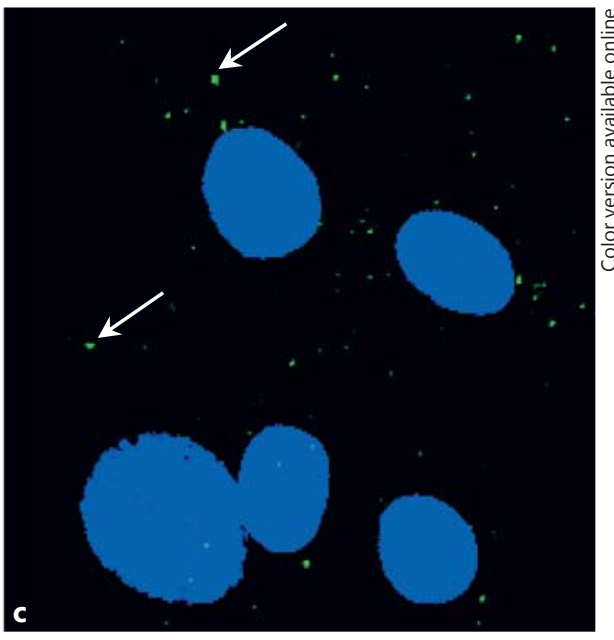

WT

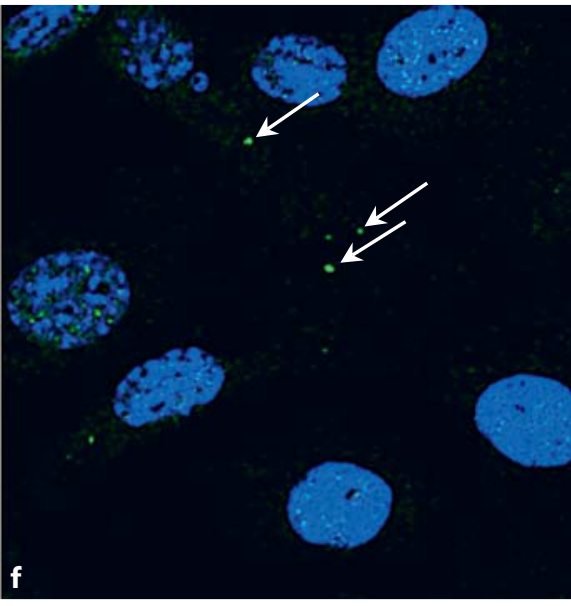

WT
Fig. 3. $\mathrm{Cx} 40$ protein distribution in $\mathrm{Cx} 40^{-/-}, \mathrm{Cx} 40^{-/-}+\mathrm{AdV}-\mathrm{Cx} 40$, $\mathrm{Cx} 40^{-/-}+\mathrm{AdV}-\mathrm{Cx} 40_{\Delta 345-358}$ and WT endothelial cells at semiconfluence. a-c Representative examples of cells probed with an antiCx40 antibody (Alpha Diagnostics) targeting the CT of Cx40. Punctate staining (arrows) denotes $\mathrm{Cx} 40$ protein plaques. The superimposed oval uniform gray shapes represent cell nuclei identified with Hoechst 33342 stain; $\mathrm{n}=2\left(\mathrm{Cx} 40^{-/-}\right), 3\left(\mathrm{Cx} 40^{-/-}+\mathrm{AdV}-\right.$ $\mathrm{Cx} 40)$ and 7 (WT). d-f Representative examples of cells probed

the cultured cells and the poor antibody performance also hampered the findings of this study. This included the low level of $\mathrm{Cx} 40$ protein in WT cells, and, in view of the high level of Cx40 mRNA expression, the less-thanexpected level of $\mathrm{Cx} 40$ protein in cells infected with AdVCx40. with an anti-Cx40 antibody targeting the cytoplasmic loop of $\mathrm{Cx} 40$ (Invitrogen). Punctate staining (arrows) denotes Cx40 protein plaques, while oval uniform gray shapes represent cell nuclei; $\mathrm{n}=$ $13\left(\mathrm{Cx} 40^{-/-}\right), 15\left(\mathrm{Cx} 40^{-/-}+\mathrm{AdV}-\mathrm{Cx} 40_{\Delta 345-358}\right)$, and 7 (WT). b, e Dashed lines represent approximate cell borders. d-f The nonpunctate staining was judged as nonspecific antibody background staining. Bar $=20 \mu \mathrm{m}$.

\section{Importance of Cx40 in Intercellular Coupling}

$\mathrm{Cx} 40$ is required for the microvascular conducted response in vivo $[16,17]$. This in vitro study indicates that Cx40 also plays a modulatory role in electrical coupling in response to acute inflammatory stimuli. We reported that, in cultured WT MMEC, expression of large-size gap junction plaques of $\mathrm{Cx} 43$ protein dominates over $\mathrm{Cx} 37$ and $\mathrm{Cx} 40$ protein expression [5]. $\mathrm{Cx} 43$ may therefore be 
responsible for the baseline electrical coupling in these cells. Based on our evidence of loss of function by $\mathrm{Cx} 40$ knockout and restoration of function by the reintroduction of $\mathrm{Cx} 40$, it is intriguing that $\mathrm{Cx} 40$ may play a modulatory role in coupling during exposure to inflammatory stimuli. To this end, we suggest that $\mathrm{Cx} 40$ and $\mathrm{Cx} 43$ may be intermixing. Indeed, Cx40/Cx43 heteromeric channels have been shown to be more sensitive to stimulation than $\mathrm{Cx} 40$ or $\mathrm{Cx} 43$ homomeric channels $[18,19]$. Since $\mathrm{Cx} 40 / \mathrm{Cx} 43$ heteromeric channels are formed in vascular cells [20], the stimulus-sensitive $\mathrm{Cx} 40$ constituent of these channels present even as a minor constituent could be responsible for the modulatory role [21]. Alternatively, Cx40 could participate in this modulation, independently of its role in gap junctional intercellular communication, possibly by affecting the function of other gap junctional connexins indirectly [22]. Thus, the location of $\mathrm{Cx} 40$ protein within the cell (i.e. the cell membrane vs. the cytosol; fig. 3b) may not be critical to the response to LPS and H/R observed in this study. Examination of the potential role of $\mathrm{Cx} 40 / \mathrm{Cx} 43$ heteromeric channels and/or the indirect role of $\mathrm{Cx} 40$ during exposure to inflammatory stimuli was beyond the scope of the study.

Our results suggest that $\mathrm{Cx} 40 \mathrm{CT}$ is required for the modulation of coupling. $\mathrm{Cx} 40 \mathrm{CT}$ has been shown to play a critical role in the responses of homomeric $\mathrm{Cx} 40$ and heteromeric $\mathrm{Cx} 40 / \mathrm{Cx} 43$ channels to various stimuli $[18,23]$. We reported that the response to inflammatory stimuli in WT cells is PKA-dependent $[9,11]$. Cx40 contains a consensus sequence for PKA [24] where the $\mathrm{C}$-terminal serine residues $345,348,349$ and 353 are 4 possible PKA phosphorylation sites [25]. The lack of response here in $\mathrm{Cx} 40^{-/-}+\mathrm{AdV}$ $\mathrm{Cx} 40_{\triangle 345-358}$ cells is consistent with the possibility that these residues are important for the modulation.
Several mechanisms could explain the stimuli-induced reduction in coupling. If this reduction involved heteromeric $\mathrm{Cx} 40 / \mathrm{Cx} 43$ channels, then changes in internalization of these channels, the number of gap junctions remaining at the cell-cell surface or ZO-1 binding to $\mathrm{Cx} 40$ [26] could all affect intercellular coupling. However, because the stimuli-induced responses in $r_{i}$ occur rapidly (within 4-30 $\mathrm{min}$ ) and because $\mathrm{r}_{\mathrm{i}}$ is also restored rapidly after the removal of the stimuli $[15,27]$, the gap junction electrical behavior (i.e. altered gap junction conductance) may best explain the observed changes in $r_{i}$.

In conclusion, in mouse microvascular endothelial cells, we show that LPS, H/R and LPS $+\mathrm{H} / \mathrm{R}$ reduced electrical coupling in WT but not $\mathrm{C} \times 40^{-/-}$cells, and that this reduction was rescued by introducing $\mathrm{Cx} 40$ into the $\mathrm{Cx} 40^{-/-}$cells. If the loss of reduction were caused by a nonspecific effect of $\mathrm{Cx} 40$ knockout, then the introduction of $\mathrm{Cx} 40$ could not rescue the reduction. Introduction of $\mathrm{Cx} 40$ without the residues 345-358 did not rescue the reduction, suggesting that these residues play an important role in the reduction of coupling.

\section{Acknowledgments}

We thank Drs. Y. Ouellette, M. Bolon, F. Li, H. Wang, J. Simek, D. Bai, D. Zheng and C. Ellis, Mrs. Mary Keet for technical assistance and the Division of Vascular Surgery at London Health Sciences Center for the financial support (partial salary to K.T.). Our work was supported by grants from the Heart and Stroke Foundation of Ontario (No. T6325 and No. 000378 to K.T.).

\section{Disclosure Statement}

There are no disclosures.

\section{References}

1 Lidington D, Ouellette Y, Li F, Tyml K: Conducted vasoconstriction is reduced in a mouse model of sepsis. J Vasc Res 2003;40:149-158.

2 Tyml K, Wang X, Lidington D, Ouellette Y: Lipopolysaccharide reduces intercellular coupling in vitro and arteriolar conducted response in vivo. Am J Physiol Heart Circ Physiol 2001;281:H1397-H1406.

3 Emerson GG, Segal SS: Electrical activation of endothelium evokes vasodilation and hyperpolarization along hamster feed arteries. Am J Physiol Heart Circ Physiol 2001;280:H160H167.

4 Tyml K: Role of connexins in microvascular dysfunction during inflammation. Can J Physiol Pharmacol 2011;89:1-12.
5 McKinnon RL, Bolon ML, Wang HX, Swarbreck S, Kidder GM, Simon AM, Tyml K: Reduction of electrical coupling between microvascular endothelial cells by NO depends on connexin37. Am J Physiol Heart Circ Physiol 2009;297:H93-H101.

6 Iacobas DA, Scemes E, Spray DC: Gene expression alterations in connexin null mice extend beyond the gap junction. Neurochem Int 2004; 45:243-250.

7 Brisset AC, Isakson BE, Kwak BR: Connexins in vascular physiology and pathology. Antioxid Redox Signal 2009;11:267-282.
8 Swarbreck S, Secor D, Li F, Gross PL, Ellis CG, Sharpe MD, Wilson JX, Tyml K: Effect of ascorbate on fibrinolytic factors in septic mouse skeletal muscle. Blood Coagul Fibrinolysis 2014;25:745-753.

9 Bolon ML, Peng T, Kidder GM, Tyml K: Lipopolysaccharide plus hypoxia and reoxygenation synergistically reduce electrical coupling between microvascular endothelial cells by dephosphorylating connexin40. J Cell Physiol 2008;217:350-359.

10 He P, Curry FE: Measurement of membrane potential of endothelial cells in single perfused microvessels. Microvasc Res 1995;50: 183-198. 
11 Bolon ML, Ouellette Y, Li F, Tyml K: Abrupt reoxygenation following hypoxia reduces electrical coupling between endothelial cells of wild-type but not connexin 40 null mice in an oxidant- and PKA-dependent manner. FASEB J 2005; 19:1725-1727.

12 Vargas FF, Caviedes PF, Grant DS: Electrophysiological characteristics of cultured human umbilical vein endothelial cells. Microvasc Res 1994;47:153-165.

13 Gustafsson F, Mikkelsen HB, Arensbak B, Thuneberg L, Neve S, Jensen LJ, HolsteinRathlou NH: Expression of connexin 37, 40 and 43 in rat mesenteric arterioles and resistance arteries. Histochem Cell Biol 2003;119: 139-148.

14 Jersmann HP, Hii CS, Hodge GL, Ferrante A: Synthesis and surface expression of CD14 by human endothelial cells. Infect Immun 2001; 69:479-485

15 Lidington D, Ouellette Y, Tyml K: Endotoxin increases intercellular resistance in microvascular endothelial cells by a tyrosine kinase pathway. J Cell Physiol 2000;185:117-125.

16 de Wit C, Roos F, Bolz SS, Kirchhoff S, Kruger $\mathrm{O}$, Willecke K, Pohl U: Impaired conduction of vasodilation along arterioles in connexin 40-deficient mice. Circ Res 2000;86:649655.
17 Wang L, Yin J, Nickles HT, Ranke H, Tabuchi A, Hoffmann J, Tabeling C, Barbosa-Sicard E, Chanson M, Kwak BR, Shin HS, Wu S, Isakson BE, Witzenrath M, de Wit C, Fleming I, Kuppe H, Kuebler WM: Hypoxic pulmonary vasoconstriction requires connexin 40-mediated endothelial signal conduction. J Clin Invest 2012;122:4218-4230.

18 Stergiopoulos K, Alvarado JL, Mastroianni M, Ek-Vitorin JF, Taffet SM, Delmar M: Heterodomain interactions as a mechanism for the regulation of connexin channels. Circ Res 1999;84:1144-1155.

19 Gu H, Ek-Vitorin JF, Taffet SM, Delmar M: Ultrarapid communication: coexpression of connexins 40 and 43 enhances the $\mathrm{pH}$ sensitivity of gap junctions: a model for synergistic interactions among connexins. Circ Res 2000; 86:1100.

20 He DS, Jiang JX, Taffet SM, Burt JM: Formation of heteromeric gap junction channels by connexins 40 and 43 in vascular smooth muscle cells. Proc Natl Acad Sci USA 1999;96: 6495-6500.

21 Burt JM, Steele TD: Selective effect of PDGF on connexin 43 versus connexin 40 comprised gap junction channels. Cell Commun Adhes 2003; 10:287-291.

22 Yu G, Bolon M, Laird DW, Tyml K: Hypoxia and reoxygenation-induced oxidant production increase in microvascular endothelial cells depends on connexin40. Free Rad Biol Med 2010;49:1008-1013.
23 Anumonwo JM, Taffet SM, Gu H, Chanson M, Moreno AP, Delmar M: The carboxyl terminal domain regulates the unitary conductance and voltage dependence of connexin 40 gap junction channels. Circ Res 2001;88:666673

24 Blom N, Gammeltoft S, Brunak S: Sequence and structure-based prediction of eukaryotic protein phosphorylation sites. J Mol Biol 1999;294:1351-1362.

25 Hjerrild M, Stensballe A, Rasmussen TE, Kofoed CB, Blom N, Sicheritz-Ponten T, Larsen MR, Brunak S, Jensen ON, Gammeltoft S: Identification of phosphorylation sites in protein kinase A substrates using artificial neural networks and mass spectrometry. J Proteome Res 2004;3:426-433.

26 Bouvier D, Kieken F, Kellezi A, Sorgen PL: Structural changes in the carboxyl terminus of the gap junction protein connexin 40 caused by the interaction with $\mathrm{c}-\mathrm{Src}$ and zonula occludens-1. Cell Commun Adhes 2008; $15: 107-118$

27 Rose K, Ouellette Y, Bolon M, Tyml K: Hypoxia/reoxygenation reduces microvascular endothelial cell coupling by a tyrosine and MAP kinase dependent pathway. J Cell Physiol 2005;204:131-138. 